\title{
Central venous catheter-related bloodstream infection - prevention, records and auditing
}

\author{
AV Varela ${ }^{*}$, P Vala², M Dykyy², R Almeida², J Arduán², A Gonçalves², MA Pereira², I Hubert², C Granja ${ }^{2}$ \\ From ESICM LIVES 2015 \\ Berlin, Germany. 3-7 October 2015
}

\section{Introduction}

Central venous catheterization is commonly used in critically ill patients and may cause different complications, including infection. This type of infection contributes to morbidity, mortality and, as a consequence, to the increase in health care costs.

\section{Objectives}

Evaluation of the incidence and adherence of the ICU team to an implemented protocol for prevention of central venous catheter- related bloodstream infection (CVCRBI).

\section{Methods}

Exploratory-descriptive research based in auditing an implemented protocol through the use of checklists. After CVC- related bloodstream infection prevention protocol implementation, auditing was made during the period of 26 of November of 2014 to 3 of March of 2015. Population study: 17 doctors and 36 nurses were under observation. Auditing was made in random labor time of the investigators. Auditing checklists:

1- evaluation during insertion of $\mathrm{CVC}$;

2 - evaluation during maintenance and removing of CVC.

\section{Results}

From all the 185 in-patients in the ICU, 141 had CVC. Mean age was 61 years old, $54 \%$ were males, mean length of ICU stay was 7 days. Type of admission: $49 \%$ medical; $18 \%$ elective surgery; $23 \%$ urgent surgery; $7 \%$ trauma; $3 \%$ potential organ donors. Mean SAPS II was 48; mean SOFA was 7. Overall catheter day's was 1196 that corresponds to $1,7 \%$ of CVCRBI. A total of 119 auditings were

${ }^{1}$ Centro Hospitalar do Algarve, Hospital de Faro, Intensive Care Unit 1-Faro, Faro, Portugal

Full list of author information is available at the end of the article made (23 during insertion; 89 during maintenance and 3 during removal).

Audit results: compliance with protocol during insertion of CVC - 87\%; compliance with protocol during maintenance was $83 \%$.

\section{Conclusions}

During the audit period we had a low incidence of CVCRBI. Compliance with implemented protocol was very high. During the same period the ICU mortality rate decreased. Although direct correlation can't be made, we might speculate, that the incidence of CVCRBI's could aid, in same way, to this decrease in mortality.

\section{Authors' details}

${ }^{1}$ Centro Hospitalar do Algarve, Hospital de Faro, Intensive Care Unit 1-Faro, Faro, Portugal. ${ }^{2}$ Centro Hospitalar do Algarve, Hospital de Faro, Faro, Portugal.

Published: 1 October 2015

doi:10.1186/2197-425X-3-S1-A887

Cite this article as: Varela et al:: Central venous catheter-related

bloodstream infection - prevention, records and auditing. Intensive Care Medicine Experimental 2015 3(Suppl 1):A887.

Submit your manuscript to a SpringerOpen ${ }^{\odot}$ journal and benefit from:

- Convenient online submission

- Rigorous peer review

- Immediate publication on acceptance

- Open access: articles freely available online

- High visibility within the field

- Retaining the copyright to your article

Submit your next manuscript at $\gg$ springeropen.com

\section{SpringerOpen ${ }^{\circ}$}

C 2015 Varela et al.; This is an Open Access article distributed under the terms of the Creative Commons Attribution License (http:// creativecommons.org/licenses/by/4.0), which permits unrestricted use, distribution, and reproduction in any medium, provided the original work is properly cited. 